\title{
Die verhouding tussen kerk en staat: Enkele modelle met verwysing na die reg van opstand teen die staat
}

\author{
DJ Smith
}

\section{Abstract}

The interrelationship between church and state: Some theological models with reference to the right to revolt against the state

In this paper consideration is given to the theological models concerning the relation church and state, as accepted by the Roman Catholic Church, Luther, Calvin, Karl Barth and the theologies with a revolutionary inclination like the Political Theology, Theology of Liberation, Revolutionary Theology and the Kairos Document. The right to revolt against the state, as perceived within each model, is also dealt with.

Die verhouding tussen kerk en staat kom in ons dag weer sterk op die voorgrond in die teologiese gesprek. Hierdie gesprek is nie net in Suid-Afrika nie, maar ook wêreldwyd aan die gang. Die redes waarom hierdie gesprek nuwe lewe gekry het, lê enersyds daarin dat die voortgaande proses van sekularisasie 'n groterwordende verwydering tussen kerk en staat tot gevolg het. Die gevolg is dat die gevestigde kerke gedwing word om opnuut daaroor na te dink of die terme waarin hulle die verhouding tussen kerk en staat uitdruk, voldoende is om reg te laat geskied aan die eise van die tyd. Andersyds het ons ook te doen met die baie meer kritiese en selfs militante houding teenoor die staat van sekere groeperinge in sekere kerklike kringe wat beïnloed word deur gedagtes vanuit die Politieke Teologie, die Teologie van Bevryding, die Teologie van Revolusie en die Swart Teologie. In dié kringe gaan hulle veel verder as om net vanuit die Woord teenoor die staat te getuig. Daar is ' $n$ neiging om voorskrywend te wees met betrekking tot sekere aspekte van die staatsbeleid en selfs 'n bereidheid om betrokke te wees by ' $n$ rewolusionêre omverwerping van staatsgesag. Dit is dringend noodsaaklik $d_{\imath}$ t die kerk ' $n$ antwoord sal gee op hierdie radikale sieninge oor die verhouding tussen kerk en staat.

Ons wil in hierdie artikel 'n opsomming gee van die belangrikste 
teologiese modelle om die verhouding tussen kerk en staat te skilder en ook enkele kritiese opmerkings daarby maak. Hierbenewens wil ons ook ingaan op die vraag na die reg tot opstand teen die gesag van die staat soos dit in hierdie modelle beantwoord word. Ons wil eindig by die vraag na 'n teologiese model wat geskik is vir ons dag.

\section{DIE TEOLOGIESE MODEL VAN DIE ROOMS-KATOLIEKE KERK}

Die Rooms-Katolieke Kerk se opvatting word bepaal deur hulle natuurgenade denkskema. Die staat is hiervolgens dan 'n oorspronklike skeppingsordening wat reeds met die skepping gegee is en is nie, soos die opvatting in die kringe van die Kerkhervorming was, ' $n$ ordening wat sy oorsprong in die eerste plek in die sondeval en sonde het nie. Vanuit die natuur waarmee die mens geskape is, het die mens ' $n$ natuurlike drang om tot staatsvorming oor te gaan. Hierdie natuurdrang is aan die drang van die redelik-sedelike wil van die mens verbind. Vanuit die Rooms-Katolieke leer van die analogia entis stel hulle dat die lex naturae 'n afglansing is van die lex aeternae van God. Die mens het dus 'n sekere natuurlike kennis van God en die verhoudinge wat $\mathrm{Hy}$ daargestel het. Dit geld ook van die wese van die staat. So is dit dus moontlik om die wese van die staat vanuit die natuurlike wese van dinge, byvoorbeeld die sosiale filosofie, te leer ken.

Hierby kom die tweede belangrike gedagte wat aan die idee van ' $n$ skeppingsordening gekoppel is, naamlik dat die staat te alle tye aan homself gelyk bly omdat hy sy oorsprong in die altyd wesenlike gelyke menslike natuur het.

As ' $n$ instelling van God is die mag van die staat ' $n$ 'toelatende (permissiewe)' uitdrukking van God se wil en moet die onderdaan hom aan die staat onderwerp in soverre die staat sy plig doen om die belang van sy onderdane te dien.

Die Tomistiese teologie stel egter ook dat die natuurlike rede nie in staat is om sonder die genade die godgegewe ordeninge en daarom ook die ware wese van die staat ten volle te ken nie. Die staat het dus die leiding van die kerk nodig om sy ware opdrag te ken. Daarom staan die kerk in der waarheid bo die staat, maar op so 'n manier dat die kerk nie in die soewereiniteit en reg van die staat ingryp nie, maar veel eerder die staat help om sy eie wese te ken en op laer vlak as die kerk God se 
wil te verwerklik. In hierdie verband het hulle die spreuk, 'Gratia non destruit sed perficit naturam' ontwerp.

Die Rooms-Katolieke Kerk word dus deur die optimistiese gedagte gelei dat waar die staat sy eie wese reg verstaan, daar harmonie tussen die staat en die Rooms-Katolieke Kerk sal wees. Waar die RoomsKatolieke Kerk vroeër kon leer dat die kerk op die terrein van die genade meer openlik leidinggewend bo die staat kan staan, het die hedendaagse stand van sake op staatkundige terrein met die toenemende sekularisering van die staat, ietwat ontnugterend op hulle siening ingewerk en leer hulle net ' $n$ indirekte mag van die kerk oor die staat (vgl Thielicke 1974: 670-698, Kreck 1975: 296-301 en Sфe 1965: 320-323).

Wat die reg tot opstand teen die gesag van die staat betref, het die Rooms-Katolieke Kerk nog altyd 'n positiewe waardering van die staatsmag gehad en laat geen reg tot aktiewe weerstand teen die staat toe nie. Die verste wat ' $n$ mens kan gaan, is om gehoorsaamheid te weier, maar verder moet ' $n$ mens maar in gebed onder so ' $n$ slegte regering buig en dit as 'n beproewing van God beskou (Sфe 1965: 349). Kreck wys daarop dat daar wel 'n gedagterigting by 'n sekere groep teoloë binne die Moraal-teologie is wat wel in uiterste gevalle die reg tot aktiewe weerstand teen die staat toelaat (Kreck 1975: 329, 330). By nadere ondersoek van hierdie standpunt blyk dit dat daar in die gewone gang van sake selfs by dié gedagterigting maar weinig sprake is van 'n reg tot opstand. Dit blyk uit 'n uiteensetting wat Lotz (1965: 83) gee oor wanneer die reg tot aktiewe weerstand ter sprake kom. Hy sê dat dit alleen op natuurregtelike gronde beslis kan word of die staat in diens van die reg of onreg staan en of 'n opstand teen die gesag van die staat geregverdig is of nie. Die reg tot aktiewe opstand kom eers ter sprake wanneer 'n mens met 'n totalitêre staat te doen het. Die totalitêre staat kan dan vanuit die natuurreg aan die volgende twee kenmerke geken word:

- As die staat geen onafhanklike, onaantasbare reg buite homself erken nie en homself as die bron van alle reg sien en dus na willekeur regeer;

- As die staat die vryheid en waardigheid van die mens, as onbegrensde waarde, teoreties bestry en prakties onderdruk.

In so 'n geval kan 'n mens, vanuit die natuurreg gesien, hom verset as hy in 'n totalitêre staat tot die dood toe bedreig word en is die reg tot opstand daar. 
Hierdie opvatting is geensins dié van die Rooms-Katolieke Kerk nie, maar is net na vore gebring as die opsigtelike uitsondering op die algemene afwysing van die reg tot aktiewe weerstand. In elke geval lê die swakheid van hierdie opvatting juis daarin dat dit geheel en al op natuurregtelike gronde berus.

Die vraag waaraan ons nou wil aandag gee is: Is die Rooms-Katolieke model vir die verhouding van kerk en staat bruikbaar en aanvaarbaar binne 'n Bybelse teologie? Die positiewe aspekte van hierdie model is dat dit skynbaar daarin slaag om die gesag van kerk en staat op positiewe wyse in verbinding met mekaar te bring, dat dit poog om 'n absolute outonomie van die staat aan bande te lê en dat dit ruimte laat vir'n wye verskeidenheid van staatsvorme wat uit die natuurreg kan ontwikkel.

Die natuur-genade filosofie en die leer van die analogia entis asook die Natuurteologie waarop hierdie model berus, maak dit egter onaanvaarbaar vir 'n Bybels-reformatoriese teoloog. Dit blyk ook dat hierdie model net werklik goed werk waar die belange van kerk en staat saamval en waar die Rooms-Katolieke Kerk die leiding in die samelewing het en waar daar nog iets van die middeleeuse corpus christianum gedagte kan herleef. Hierby is dit ook so dat hoe meer gesekulariseerd die staat word, hoe moeiliker word dit om hierdie model te handhaaf.

\section{DIE TEOLOGIESE MODEL VAN LUTHER}

Luther gaan uit van 'n skerp onderskeid tussen die wêreldlike regering (gesetel in die staat) en die geestelike regering (gesetel in die kerk). Hy word hierin gelei deur Augustinus se gedagtes in sy De Civitas Dei, waar Augustinus sê dat die Christen 'n tweërlei burgerskap het. Hy het 'n hemelse burgerskap as burger van die Godstad, maar hy is ook burger van ' $n$ bepaalde aardse stad. Daar is dan ' $n$ baie duidelike onderskeid tussen die geestelike regering waar God self deur die Evangelie en die Heilige Gees regeer om vrome Christene te skep, en die wêreldlike regering wat deur dwang en straf ' $n$ wal teen die sonde moet opwerp en so uiterlike vrede en orde tot stand moet bring.

Die staat se oorsprong lê primer in dié feit dat die mens in sonde geval het en die staat dus as so ' $n$ 'dwangordening' nodig geword het om die wanorde van die sonde teen te werk (dit is dus nie 'n skeppingsordening nie).

Hoe weet ' $n$ mens wat is die regte manier om 'n regering op 
wêreldlike vlak in te rig? Luther wys op die lex naturalis wat direk deur die ratio geken kan word - daarom vind ' $n$ mens dikwels voortreflike regerings onder die heidene. Onder lex naturalis verstaan hy iets anders as die Rooms-Katolieke lex naturae. Hy aanvaar deeglik dat die sonde die mens se oorspronklike kennis van God en sy wil verduister het, maar aanvaar tog ook dat daar iets van daardie oorspronklike kennis oorgebly het. Daarom aanvaar hy dat die Here die wêreldlike regering aan die verstand onderwerp het, dit wil sê dat dit vanuit redelike insigte ontwerp kan word.

Luther wil die ratio tog wel nie aan homself oorlaat nie, daarom stel hy ook dat die vorste, die regeerders, wel persoonlik ook die regte Godsvrees moet leer ken om die ratio reg te kan gebruik vir die regering van die land.

In die praktyk het dit egter later so verloop dat die Lutherse Ortodoksie die onderskeid tussen kerk en staat veel skerper getrek het as Luther self, tot so 'n punt dat wat Luther onder ratio verstaan het, geheel en al aan homself oorgelaat is (Sфe 1965: 326-327) en het sake in die Lutherse kerk ná Luther gou tot 'n punt ontwikkel wat teenstrydig was met Luther se aanvanklike bedoeling. Juis op grond van die onderskeid wat Luther gemaak het, het die Lutherse Ortodoksie die fout gemaak om te dink dat die 'Godsryk' slegs tot die innerlike en geestelike sy van die kerklike lewe behoort en het hulle daarom alle uiterlike sake - ook die uiterlike beheer en administrasie van die kerk - aan konfessioneel gebonde heersers oorgelaat. Dit het in die tyd van die opbloei van die Lutherse Ortodoksie gelei tot 'n geestelike dwang en 'n staatsheerskappy oor die kerk se verkondiging en hieruit kan ook sekere latere ontwikkelinge tot staatsabsolutisme afgelei word. (Vir die Lutherse opvatting kyk Diem 1973: 1-173), De Quervain 1945: 203-205; Kreck 1975: 302-307, Sфe 1965: 323-327.)

Die konserwatiewe Lutherse kring benader die reg tot opstand teen die staat vanuit die agtergronde van die leer van die 'twee ryke'. Vanuit hierdie leer stel hulle dat ons volgens Romeine 13 aan die bestaande staatsorde moet vashou in soverre dit nog enigsins ' $n$ ordeningsfunksie uitoefen, onder andere omdat die staat 'n 'Erhaltungsordnung', 'n handhawingsordening of instandhoudingsordening is. Daar is drie grense vir die staat se mag waaraan die staat hom moet hou en dit lê in:

- die verhouding van die empiriese staatsowerheid tot sy goddelike mandaat; 
- die menswaardigheid wat gerespekteer moet word; en

- die erkenning van die Christelike Kerk en sy regte.

Selfs al sou die staat oortree wat hierdie grense betref, moet die Christen se optrede slegs tot passiewe weerstand en die weiering van gehoorsaamheid beperk bly. Die reg tot aktiewe weerstand is iets wat slegs in uiterste omstandighede ter sprake kom en dan is dit nie veel meer as ' $n$ teoretiese moontlikheid nie. In so ' $n$ geval moet dit in elk geval oorgelaat word aan ingeligte mense met 'n verantwoordelike posisie in die staatsbestel of amptenare van die staat wat werklike insig in die verwording van die staat het, om op te tree. Daar kan nie sonder werklike insig opgetree word nie en dit sluit die gewone burger uit (Kunneth 1956: 93-100; ook Hechel 1956: 32-45).

Die positiewe aspekte van die Lutherse teologiese model is dat dit goed daarin slaag om 'n vermenging en grensoorskryding van die opdrag en roepingsvervulling van kerk en staat te voorkom, dat dit sterk ingestel is op die handhawing van orde en die voorkoming van wanorde in die gemeenskap, en dat dit ook, reg verstaan, aan 'n gelowige 'n groot mate van gewetensvryheid gee en ook die onaantasbaarheid van die geloof uitspel in ons verhouding met die staatsowerheid, soos Asendorf dit ook beklemtoon (Asendorf 1986: 37).

Die negatiewe aspekte van hierdie teologiese model is dat daar met 'n verkeerde klem op die leer van die 'twee ryke' 'n geneigdheid by die kerk kan ontstaan tot ' $n$ algehele onttrekking in die geestelike sfeer met 'n gevolglike onbetrokkenheid by staatsake en sosiale sake waar 'n staatsbetrokkenheid ter sprake is. Die teendeel hiervan is dat daar ruimte gelaat kan word vir 'n ontwikkeling van staatsabsolutisme en totalitêre tendense in die staat.

Die gesprek rondom Luther se leer van die twee ryke het in ons dag weer opnuut opgevlam in Europese kringe. Die sterk prikkel hiertoe was die verskyning van HM Kuitert se boek: 'Alles is politiek, maar politiek is niet alles - een theologische perspectief op geloof en politiek' (Kuitert 1985). Uit resensies in Nederlandse tydskrifte wil dit voorkom asof hierdie boek geweldige sterk reaksies uitgelok het. Kuitert staan in hierdie boek 'n nuwe interpretasie van Luther se 'twee ryke'-leer voor. Die resensies wat ek onder oog gehad het, het almal 'n sterk afwysende toon teenoor Kuitert se standpunt (in H N Magazine - Heering 1986: 16, 17 en 19; Van Heist 1986: 27-29; Verbeek 1986: 10-13 en in Evangelisch Commentaar - Mulder 1986: 14-16; asook in Centraal Weekblad - Runia 1985: 3 en 8). Uit die reaksies blyk 'n soort vreesagtigheid dat die kerk 
met die aanvaarding van Kuitert se standpunt oor die 'twee ryke'-leer'n politieke seggenskap indien nie dalk 'n soort politieke magsbasis teenoor die staat sal verloor nie. Dit is in elk geval hoe ek dit tussen die lyne deur lees.

Hierdie sensitiwiteit teenoor Kuitert laat blyk in elk geval duidelik dat dit wel nodig is dat daar weer aan Luther se standpunt aandag gegee word in ons tyd waarin baie kerke op 'n breërwordende front politieke betrokkenheid aanvaar en waarin ons ook met die Politieke Teologie en Teologie van Bevryding en sy uitlopers te doen het. Om dié rede sal dit ook loon om Kuitert se boek diepgaande na te gaan.

Luther se teologiese model het in elk geval diep Bybelse en historiese wortels. Die Bybelse wortels lê in Filippense 3: 20 en 21 en Hebreërs 11. Roldanus (1985: 265 -283) onderskei drie lyne in die gebruik van die gedagte van die tweërlei burgerskap van die Christen in die vroeë kerk. Daar is eerstens die lyn wat slaan op die Christene se lewenstyl en askese in die samelewing waar die vreemdelingskap in die wêreld sien op 'n lewenstyl van relativering van alle aardse goedere. Clemens van Alexandrië en Johannes Chrysostomos is hier voorbeelde (Roldanus 1985: 272-274).

Tweedens is daar die lyn van 'n vergelyk met die politieke werklikheid waar die Christene medeverantwoordelikheid aanvaar vir die staat se welsyn. Die twee ryke staan nie teenoor mekaar nie, maar die burgerskappe vloei saam. As 'n pelgrim op pad na sy ewige Vaderland dra die Christen tog volle verantwoordelikheid jeens sy aardse Vaderland. Hier het ons te doen met 'n vergelyk met die staat, met ' $n$ versoening en versmelting van die twee burgerskappe. Tertullianus, Origenes, Eusebius en Ambrosius is voorbeelde (Roldanus 1985: 274-278).

Die derde lyn is die pastorale lyn van die kerk as eskatologiese gemeenskap waar die kerk onafhanklik van die staat leef in die vooruitsig op die hemelse Vaderland. Die kerk kan egter in vryheid en onafhanklikheid van die toevallige politieke konstellasies gebruik maak en sy bydrae aanbied. Dié siening vind ons by Cyprianus en Augustinus (Roldanus 1985: 278-282).

Roldanus gee ook 'n waardering van die onderskeie lyne (Roldanus 1985: 282 en 283). Die positiewe aspek van die lyn van 'n ongewone lewenstyl is dat dit ruimte skep vir 'n lewenstyl waarin God se wil volbring word. Negatief hou dit die gevaar in dat' $n$ mens kan oorgaan tot ' $n$ moralistiese voorskryf van 'n moeilik haalbare ideaal en onderwaardering van die aardse werklikheid. 
Die positiewe betekenis van die lyn van politieke betrokkenheid is dat die gelowige besef hy behoort aan 'n ryk wat hierdie wêreld binnedring. Aan die negatiewe kant kan daar 'n verflouing van die eskatalogiese spanning tussen die twee ryke kom en kan daar'n verlies van kritiese funksie teenoor ideologeë plaasvind en kan vooruitgangsoptimisme en historiese prestasies maklik met God se bedoeling gelykgestel word.

Die positiewe betekenis van die lyn van die kerk as eskatologiese gemeenskap is dat dit aandag gee aan die tydsomstandighede waaronder Christene leef en Christene in staat stel om onder die teken van voorlopigheid in te gaan op die positiewe en bruikbare aspirasies van die politieke gemeenskap sonder om dit te idealiseer of ideologiseer. Negatief kan dit lei tot 'n opportunisme en geneigdheid om net die belange van die kerk in gedagte te hou.

Dit blyk dus dat die uitsprake van die vroeg-Christelike kerkvaders heelwat moontlikhede bied om vir ons moderne tyd nuwe perspektiewe op Luther se leer van 'twee ryke' te bied. Voeg ons hierby Kuitert se moderne interpretasie van hierdie leer en neem ons ook Asendorf se uitspraak in ag dat Luther se 'twee ryke'-leer ' $n$ 'Kampflehre' is teen die magte wat die vryheid van die evangelie en die geloof ten diepste bedreig en dat dit staan vir vryheid van gewete en die onaantasbaarheid van die geloof (Asendorf 1986: 37), dan is dit duidelik dat ons weer moet kyk na die moontlikhede wat hierdie model vir ons moderne tyd inhou. By ' $n$ herwaardering van hierdie model moet daar ook in gedagte gehou word dat daar 'n goeie saak voor uitgemaak kan word dat Nederduitsch Hervormde Kerk in sy opvatting oor kerk en staat sterk deur Luther se gedagtes beïnvloed is.

\section{DIE TEOLOGIESE MODEL VAN CALVYN}

Calvyn gaan ook van 'n onderskeid tussen kerk en staat uit. Elk het sy eie selfstandigheid. Calvyn trek die onderskeid egter nie tot 'n totale geskeidenheid deur nie, want daar is tog raakpunte en 'n terrein waar die Bybel samewerking eis. Daar is dus nie ' $n$ volslae dualisme nie.

Waar kom die raakpunt tussen kerk en owerheid ter sprake volgens Calvyn? Die staat is deur God ingestel vanweë die verdorwenheid (en sonde) van die menslike geslag. Die staat as ' $n$ instelling van God, is, soos alle ander skepsels, met een groot doel daar, naamlik om God se eer te verhoog. Daarom is die owerheid in sy regering aan God se 
Woord en in besonder aan God se Wet gebind. Die owerheid se taak strek oor beide tafels van die Wet. God se wil word wel ook in die natuur en rede gegee, maar daardie kennis is geheel en al verduister, daarom kan ons alleen uit God se Woord aflei wat die regte staat is, dit wil sê die inrigting van die staat en sy regering.

Hoewel kerk en staat onderskeie en selfstandig is, verkeer hulle nie in stryd nie. Die een is veronderstel om die ander in sy taak te ondersteun. Die owerheid het die taak om alle ergernisse in die weg van die ware Godsdiens uit die weg te ruim, selfs met die mag van die swaard (soos omskrywe in die Nederlandse Geloofsbelydenis Artikel 36 - 'n artikel wat tans probleme skep vir baie Calvinistiese teoloë), terwyl die kerk van sy kant deur vermaning en toepassing van die tug die owerheid moet ondersteun deur te sorg dat daar nie so baie mense sondig nie (Calvynse Institusie: IV, XI, 3). Die owerheid het dus 'n plig tot beskerming van God se Woord sonder om op die kerk se terrein te oortree en net so het die kerk 'n plig om die owerheid te ondersteun sonder om op die owerheid se terrein te oortree. In Calvyn se siening is kerk en staat dus wel onderskei, maar hoort dit prakties en feitelik tesame.

Daar is ' $n$ teokratiese tendens in Calvyn se gedagtes oor kerk en staat en daarvolgens staan die staat, nes soos die kerk, onder 'n teokrasie, dit wil sê 'n koningsheerskappy van Christus. Hierdie teokrasie beteken nie dat die kerk onderworpe is aan die staat nie. In hierdie teokratiese denke lê die ware skeiding in die verhouding van kerk en staat tussen die Woord van God en die owerheid wat hom daaraan onderwerp aan die een kant, en die Woord van God en die owerheid wat hom nie daaraan onderwerp nie aan die ander kant (Calvyn se Institusie: IV: XX; Thielicke 1974: 699-756; Sфe 1965: 327-330; De Quervain 1945: 206-208).

Calvyn het 'n sterk positiewe waardering vir die mag van die staat. Hierin sluit hy hom aan by die siening wat van ouds af in die kerk gehandhaaf is. Calvyn wil nie iets weet van aktiewe weerstand teen die owerheid as instelling van God nie (vgl sy standpunt tov die Franse Kerk van die Hervorming onder vervolging en stryd). Daar is slegs die weg van passiewe weerstand teen die owerheid, gerugsteun deur die getuienis van God se Woord. Calvyn voeg by dat die manier om 'n slegte owerheid te verwyder, in die kontrole wat ondergeskikte amptenare van die staat oor die leidende owerhede moet uitoefen, lê. Calvyn se siening oor die reg tot opstand word volledig bespreek in Wolf se studie (Wolf 1956: 45-58). 
Later het Beza onder andere in sy De jure magistratum, asook ander Calviniste, gestel dat 'n vors wat teen die wil van God in regeer, dit wil sê sodat die waarheid van God se Woord en die ware godsdiens vermink, verag en vertrap word, sy reg op gehoorsaamheid van die volk verloor het en dat aktiewe weerstand dan 'n plig kan word. Dit is veral John Knox wat hom in sterk taal uitgelaat het oor die reg om owerhede wat lasteraars van God is, te weerstaan (Leith 1977: 206). Sфe (1965: 350) is van mening dat die kiem van ontwikkeling van ' $n$ min of meer konsekwent natuurregtelik begronde reg tot opstand teen ' $n$ tiran soos byvoorbeeld by J Locke, vanuit hierdie opvattings van Calvyn se opvolgers kon gegroei het. Dit is egter vir my duidelik dat die breë stroom van die Calvinistiese tradisie tot en met die aanbreek van ons huidige era in die kerkgeskiedenis gekies het vir Calvyn se siening dat 'n mens se reg tot opstand beperk is tot passiewe weerstand en dat Beza-hulle se aanvaarding van ' $n$ reg tot opstand nie ter sprake gekom het nie waar die eer van God self, die waarheid van sy Woord en die ware godsdiens ter sprake gekom het.

Die Calvinistiese teologiese model ten opsigte van kerk en staat is gebou op argumente wat 'n goeie mate van gebalanseerdheid daaraan gee. Dit is egter ook so dat die Calvinistiese model veral ontwerp is met die oog op 'n samelewingstruktuur waarin daar 'n noue verband tussen kerk en staat is en die raakpunte tussen beide makliker na vore kan kom. In ons moderne samelewing waarin die staat sy funksie al hoe meer gesekulariseerd en selfs heeltemal onafhanklik van die kerk uitoefen, kan 'n mens dit toenemend moeilik vind om die model in sy volle konsekwensies toe te pas. Die uitdaging waarvoor Calvinstiese teoloë staan, is om te bewys dat die Calvinistiese teologiese model vir die verhouding van kerk en staat genoeg buigsaamheid, plooibaarheid en aanpasbaarheid het om aan die eise van ons moderne tyd te voldoen.

\section{DIE TEOLOGIESE MODEL VAN KARL BARTH}

Ons vind by Barth 'n poging tot ' $n$ Christosentriese begronding van die hele verhouding van kerk tot staat. Volgens hom kan ons nie oor die staat redeneer vanuit ' $n$ skeppingsordening of natuurwet nie, maar alleen vanuit die koningsheerskappy van Christus waarop alle mag en heerskappy van die staat gegrond is. Aan Christus behoort alle mag en heerskappy op aarde en die staat het sy mag alleen daaruit ontvang. Dit wil nie sê dat die grense tussen kerk en staat uitgewis word nie. Die 
staat het sy eie reg en selfstandigheid, maar ten spyte daarvan moet ons die heerskappy van Christus ook teenoor die staat verkondig. Selfs al sou die staat ateïsties wees, moet ons nog die volle aanspraak van Christus op alle lewensgebiede stel. Barth sê dat ons die verhouding van kerk en staat met twee konsentriese sirkels kan voorstel, met Christus as die middelpunt van albei. Alhoewel beide skerp onderskei is en die staat selfs onbewus mag wees van die kerk as die binneste sirkel, moet die koningsheerskappy van Christus nogtans vanuit die middelpunt deur die kerk na die staat uitgedra word (vgl Barth 1976). Barth se opvatting oor die reg tot opstand moet gesien word teen die agtergrond van die Christosentriese leer van die koningsheerskappy van Christus waar die volle aanspraak van Jesus Christus op alle lewensgebiede geld as ' $n$ afgrensing van die mag van die staat. Hy hou rekening met 'n situasie waar dit vir 'n mens onmoontlik word om langer gehoorsaam te wees, wel nie aan die politieke ordening nie, maar aan konkrete verteenwoordigers van die politieke ordening. Daar kan omstandighede wees waar 'n mens slegs in ongehoorsaamheid teen God en in feite in ongehoorsaamheid teen die politieke ordening, aan sekere maghebbers en regeerders gehoorsaam kan wees. 'n Mens kan te doen hê met 'n regering van leuenaars en valsaards, moordenaars en brandstigters, 'n regering wat hom in die plek van God stel, wat mense se gewetens bind, die kerk onderdruk, en homself tot die kerk van die Antichris maak. Uiteindelik kan daar net die keuse oorbly van ongehoorsaamheid teen God in gehoorsaamheid aan die regering of ongehoorsaamheid teen die regering in gehoorsaamheid aan God. Dan kan die geloof in Christus wat deur die liefde werk, dit vir ons net so noodwendig maak om aktiewe weerstand te bied as wat dit noodwendig kan wees om passiewe weerstand of positiewe samewerking aan die regering te gee in omstandighede waar' $n$ mens nie voor die uiterste keuse gestel word nie. Dan kan 'n mens se gebed vir die owerheid, sonder om op te hou bid vir die bekering en ewige heil van die regering, maklik'n gebed word vir die omverwerping van die regering en kan ons oorgaan tot 'n handeling wat ooreenstem met ons gebed (Barth 1938: 213 en 214). Barth hou dus rekening met uiterste omstandighede van uiterste verval van die regering waarin daar uiteindelik nie meer onderskei kan word tussen passiewe en aktiewe weerstand nie en waarin so 'n aktiewe weerstand nie net 'n moontlikheid nie, maar ook 'n plig word (vgl sy uitspraak oor die onontkombaarheid van ons verantwoordelikheid om wel hierdie keuse te maak as ons daarvoor gestel word (Barth 1938: 215-216). 
Barth se siening bied beslis verhelderende perspektiewe wat bydra tot ' $n$ beter begrip van die verhouding kerk en staat, maar skep tog ook die indruk dat dit baie gebruik maak van abstrakte redenasies, soms duidelik filosofies abstrakte redenasies. Die gevolg is dat 'n mens myns insiens by sommige aspekte van Barth se teologiese model eers sal moet vra of hy genoegsaam reg laat geskied aan getuienis van die Bybel wat daar te sprake kom. 'n Mens sal ook die vraag moet vra of Barth se model nie te veel oopstaan vir ' $n$ interpretasie waar daar 'n vermening van kerk en staat kan kom met die gevolglike afstomping van die geestelik-verborge aard van die koninkryk van Christus nie. Wat sy siening oor die reg tot opstand teen die staat betref, kan 'n mens nie anders as om te vra in hoeverre die siening bepaal is deur sy ervaringe met die Nazi-regering nie.

\section{DIE TEOLOGIESE MODEL VAN DIE TEOLOGIE MET ' $N$ REVOLUSIONERE STREKKING}

Ons voeg onder hierdie hoof meer as een teologiese rigting in 'n geheelbeeld saam, omdat almal deur die gemeenskaplike faktor van 'n rewolusionêre en politieke betrokkenheid saamgebind word.

JB Metz met sy Politieke Teologie het ' $n$ heel ander opvatting as wat ons tradisioneel by die teologie vind (Metz 1970: 53-90 vgl ook Metz 1971: 9-12). Sy gedagte is dat die kerk nie ' $n$ instelling is wat 'bo' of 'onder' die staat georden moet word nie, maar in werklikheid niks anders is as 'n sosiale instelling wat eenvoudig inskakel is by die sosiale werklikheid van die staatsbestel, en dat dit die taak van die kerk is om met die oog op belange van die gemeenskap, vir die stryd om vryheidsregte in te tree.

Die sogenaamde Teologie van Bevryding gaan nog 'n stap verder. Dit is ' $n$ teologiese rigting wat sy opbloei veral in Latyns-Amerika gehad het en steeds het. ' $n$ Voorstander van hierdie teologie aldaar is Gustavo Gutierez (Gutierez 1974). Hier word die onderskeid tussen kerk en staat weggeneem in 'n siening waarin die koninkryk van God (kerk) en die menslike bevrydingsgeskiedenis nog meer saamval as by JB Metz, naamlik tot so ' $n$ mate dat verlossing en bevryding in byna uitsluitlik polities-aardse terme geïnterpreteer word. Die koninkryk van God word gevestig wanneer die rewolusionêre staat na bevryding van die bestaande en onderdrukkende staatsorde tot stand kom. Daar bestaan geen twyfel oor hoe daar binne hierdie kringe oor die reg tot opstand 
teen die staat gevoel word nie. Dit word as 'n vanselfsprekendheid aanvaar. R Shaull (1969) verwoord hierdie vanselfsprekende reg baie duidelik in sy Teologie van die Revolusie. Hy is van mening dat die Christendom en die revolusie nie in teenstelling tot mekaar staan nie, maar ' $n$ onlosmaakliklike samehang vorm. Die God van die Bybel is prinsipieel 'n rewolusionêre God wat in die geskiedenis ingryp en dit op 'n doel afstuur. God self werk om die ou strukture af te breek en nuwe moontlikhede vir vryheid daar te stel. So is die Christen geroepe om met revolusie saam te werk waarin geweld dikwels onafwendbaar en noodsaaklik is.

Die sogenaamde Kairos dokument wat onlangs in Suid-Afrika verskyn het, sluit nou aan by die gedagtes van die Teologie van die Revolusie (Challenge to the Church: A Theological Comment and the Political Crisis in South Africa. The Kairos Document). Die opstellers van hierdie dokument wil hulle teologie skynbaar as ' $n$ Profetiese Teologie sien waarin mense wat by die Kerk betrokke is, soos die Ou-Testamentiese profeet, eers 'n 'social analysis' moet maak, op grond daarvan 'n sterk standpunt teen onderdrukking inneem, tirannie beveg en so uiteindelik 'n boodskap van hoop moet bring (Challenge sa: 14-21). Die kerk in sy geïnstitusionaliseerde vorm voldoen nie aan die eise van hierdie teologie nie want dit neig om vas te val in of ' $n$ sogenaamde 'state theology' of a 'church theology' wat die kerk se bevrydende aksie in die wiele ry (Challenge sa: 3-7 en 8-14). Daarom dra die dokument ook 'n sterk anti-kerklike karakter en kies dit liewer vir die uitvoer van die bevrydende aksie, vir 'n werkswyse waar individuele Christene los van die kerklike struktuur moet saamstem met en verenig in enige aksie wat van die verdruktes uitgaan om bevryding te bewerkstellig. Die kerke is verdeeld omdat die lidmate nie almal teen verdrukking verenig het en hulle verenig het met God wat altyd aan die kant van die verdrukte is nie. Dit is dan ook hierin dat geloofseenheid gevind word naamlik om in geloof en daad verenig te wees met diegene wat verdruk word. Die verdruktes is duidelik nie net beperk tot gelowige verdruktes nie, maar alle verdruktes in die algemeen, en eenheid word verstaan as eenheid met al hulle aksies - wat dit ookal mag wees - selfs dié wat dalk gekritiseer kan word (vgl Challenge sa: 22). Die Kerk moet in der waarheid sy programme, projekte, ondernemings en aktiwiteite aanpas by die stryd om bevryding. Die kerk se program en aksies moet in werklikheid geheel en al opgaan en volkome opgeneem word vir die programme en aksies van byvoorbeeld organisasies wat werklik in die saak van die onderdruktes stry (Challenge sa: 23). Die rewolusionêre 
stryd om bevryding waarin die onderdrukkende staatsmag omvergewerp word, is dus uiteindelik die allesomvattende taak van die kerk, maar dan nie meer taak van die kerk in die gewone sin van die woord 'kerk' nie, maar in die geïndiwidualiseerde vorm van indiwiduele Christene wat almal los van ' $n$ amptelike kerkband verenig in die rewolusionêre stryd om bevryding.

Hierdie teologiese model gaan mank aan groot tekortkominge waarvan die belangrikste sekerlik die eiewillige en bevooroordeelde, hantering van die Bybelse stof is, wat lei tot ' $n$ verminking en skeeftrekking van die Bybelse getuienis. Dit word duidelik gesien in die eensydige verklaring van alle eksegetiese stof in rewolusionêr-politieke terme. God word verpolitiseer en die sonde word verpolitiseer, sonde sou slegs lê in die sondige strukture wat deur 'n onderdrukkende staatsbestel geskep word en verlossing en bevryding word hoofsaaklik verstaan in terme van bevryding van hierdie onderdrukkende strukture en onderdrukkende staatsmag. In hierdie teologiese model lê daar geen heil vir die kerk nie.

Ons kan ook aandag gee aan die anabaptistiese model wat in die nadraai van die Kerkhervorming na vore gekom het en sterk afwysend teenoor die staat gestaan het. Hulle het alles wat met die staat en politieke bedrywigheid te doene gehad het, as uit die bose bestempel omdat die staat nie sy oorsprong by die instelling van God het nie, maar by die duiwel en in wese ' $n$ mag is in diens van die sonde. As mense wat onder die bedeling van die Heilige Gees leef, word hulle direk deur Hom gelei en het hulle nie so iets as die staat nodig nie. Omdat hierdie model nie werklik meer relevant is nie, laat ons dit daar.

\section{6. 'N NUWE TEOLOGIESE MODEL VIR ONS TYD?}

Van Veen (1986: 11) sê dat, toe die corpus Christianum weggeval het, die modelle vir die verhouding tussen kerk en staat wat in die WesEuropese kultuur ontwikkel het, tot 'n groot mate hulle relevansie verloor het. Die vraag wat ons moet beantwoord, is in hoe ' $n$ mate hy reg het en of dit nodig is om 'n nuwe model te ontwikkel met sin en betekenis vir ons tyd? Ons kan selfs oorweeg of 'n mens nie die verhouding van kerk en staat eerder moet beskryf by wyse van blote Bybelse riglyne in die vorm van stellings nie, waar die teologiese model meer op die agtergrond staan en nie so skerp funksioneer nie.

Watter keuse 'n mens ook al maak, is dit my oortuiging dat daar 'n 
sekere minimum aan gesigspunte in die beskrywing van die verhouding tussen kerk en staat na vore moet kom om aan die getuienis van die Bybel reg te laat geskied. Dit stip ek stellenderwyse hieronder aan:

- die erkenning van die gesag van die staat as 'n gesag wat van God kom - hoe dit ook al uitgelê word;

- die erkenning van 'n eie terrein vir onderskeidelik kerk en staat;

- die omskrywing van die verantwoordelikhede en pligte van kerk en staat soos dit mekaar raak (teologies gesien), wat ook van toepassing is op ' $n$ totaal gesekulariseerde samelewing.

- die uitleg van die voorlopigheid en eskatologiese gerigtheid van die kerk se aardse bestaan en die aanvaarding dat die kerk se roeping in laaste instansie geestelik is;

- die reg tot gewelddadige opstand teen die gesag van die wettige staatsowerheid moet so klein moontlik wees, en in elk geval ten volle reg laat geskied aan die gedagte dat die kerk se enigste wapen die swaard van die evangelie is.

\section{Literatuurverwysings}

ASENDORF, U 1986. Die bleibende Bedeutung von Luthers Regimente-Lehre: Politische Orientierung und Handlungs-anweisungen aus dem Evangelium. Diakrisis 7, 34-41.

BARTH, K 1938. Gotteserkenntnis und Gottesdienst nach reformatorischer Lehre. Zollikon: Evangelischer Verlag.

BARTH, K 1976. Rechtfertigung und Recht: Christengemeinde und Bürgergemeinde. Zurich: EVZ Verlag

BEZA, Th 1574. Concerning the rights of rulers over their subjects and the duty of subjects towards their rulers. Transl by Gonin, $\mathrm{H}$ and ed by Murray HL 1956. Cape Town: HAUM.

CALVINUS, J 1559. Institutio christianae religionis.

CHALLENGE TO THE CHURCH: A THEOLOGICAL COMMENT ON THE POLITICAL CRISIS IN SOUTH AFRICA. The Kairos document.

DE QUERVAIN, A 1945. Ethik, Bd 2: Kirche, Volk, Staat. Zollikon Evangelischer Verlag.

DIEM, H 1973. Luthers Lehre van den zwei Reiche, in Sauter, G (Hrsg), Zur zwei-Reiche Lehre Luthers, 1-133. München: Kaiser. (TB 49.)

GUTIEREZ, G 1974. Theologie van de bevryding. Baarn: Ten Haven.

HECHEL, J 1956. Stellungnahme der Kirche der Reformation - die Lutheraner, in Pfister \& Hildermann 1956: 32-45.

HEERING, $\mathrm{H}$ 1986. Kuitert en de politiek: Thuis een Franciscus en buiten een Macchiavelli. $H$ N Magazine 4 Jan 1986, bl 16, 17, 19.

HEIST, A van 1986. Geen Kuitert zonder kontekst: Blanke westerse mannen, daar blijft het bij. H N Magazine 1 Maart 1986, bl 27-29.

KRECK, W 1975. Grundfragen Christlicher Ethik. München: Kaiser.

KUITERT, HM 1985. Alles is politiek, maar politiek is niet alles: Een theologisch perspectief op geloof en politiek. Baarn: Ten Haven.

KUNNETH, W 1956. Die heutige Position - theologisch, in Pfister \& Hildermann 1956: 93-100. 
LEITH, JH 1977. Introduction to the reformed tradition. 2nd ed. Atlanta: John Knox.

LOTZ, SJ 1956. ' $n$ Weergawe van sy gesprek as inleier op gelewerde referate, in Pfister \& Hildermann 1956: 83.

METZ, JB 1970. Kirchliche Autorität im Anspruch der Freiheitsgeschichte, in Metz, JB, Mollmann, J \& Oelmüller, W, Kirche im Prozess der Aufklärung: Aspekte einer 'neunen' politischen Theologie. München: Kaiser.

METZ, JB 1971. Politische Ethik, in Assig H \& Trutwin, W (Hrsg), Politische Ethik, 9-12. 2 Aufl. Göttingen: Vandenhoeck \& Ruprecht. (Quellentexte zum Religiensunterricht 17.)

MULDER, DC 1986. Niet alles is politiek. Evangelisch Commentaar 24 Januarie 1986, bl 14-16.

PFISTER, B \& HILDERMANN, G (Hrsg) 1956. Widerstandsrecht und Grenzen der Staatsgewelt: Bericht über die Tagung der Hochschule für politische Wissenschaften, München, und der evangelische Akademie, Tutzing, 18-20 Juni 1955. Berlin: Duneker \& Humblodt.

ROLDANUS, I 1985. Tweeërlei burgerschap van de Christen. Vroegchristelijke modellen van terughouding en engagement ten opsigte van de politieke gemeenskap. Kerk en Theologie 36, 265-283.

RUNIA, K 1985. Terugkeer tot de twee-rijken leer: Kerk zoekt geen macht. Centraal Weekblad 15 Nov 1985, bl 3 en 8.

SHAULL, R 1969. Uitdaging aan kerk en maatschappij, verandering, vernieuwing, bevrijding. Baarn: Wereldvenster.

$\mathrm{S} \emptyset \mathrm{E}, \mathrm{NH}$ 1965. Christliche Ethik: Ein Lehrbuch. 3. Aufl. München: Kaiser.

THIELICKE, H 1974. Theologische Ethik, 2. Bd, 2. Teil: Ethik des politische. 3. Aufl. Tübingen: Mohr.

VAN VEEN, JE 1986. Interkerklijk werkverband of Christelijke Organisatie: Kanttekeningen bij modellen over de verhouding geloof, kerk en politiek. Evangelisch Commentaar 21 Maart 1986, bl 11.

VERBEEK, H 1986. Een schadelijk virus dat om zich heen grijpt: Kuitert hakt de mens in tweeën. H N Magazine 18 Januarie 1986, bl 10-13.

WOLF, E 1956. Das Problem des Widerstandsrechts bei Calvin, in Pfister \& Hildermann 1956: 45-58. 